\title{
Effects on inbreeding of different strategies aimed at eliminating scrapie sensitivity alleles in rare sheep breeds in The Netherlands
}

\author{
J. J. Windig ${ }^{1}+$, H. Eding ${ }^{1}$, L. Moll ${ }^{2}$ and L. Kaal ${ }^{1}$ \\ ${ }^{1}$ Animal Sciences Group, Wageningen University and Research, Division Animal Resources Development (DEO), PO \\ Box 65, 8200 AB Lelystad, The Netherlands \\ ${ }^{2}$ Dutch Animal Health Service, PO Box 9, 7400 AA Deventer, The Netherlands \\ † E-mail : Jack.Windig@wur.nl
}

\begin{abstract}
The Dutch scrapie eradication programme aims at the exclusive use of homozygous ARR/ARR breeding rams by the end of 2004. As a consequence, breeds with a small population size and a low frequency of the ARR allele may suffer unacceptable losses of genetic diversity and high inbreeding levels. We simulated three breeding strategies to assess their efficacy in eliminating scrapie sensitive alleles and their effect on inbreeding levels. Under mild selection, both homozygous and heterozygous ARR rams were used indiscriminately. Under moderate selection, homozygous ARR rams were used preferably but they were supplemented with heterozygous rams when necessary. Under severe selection, only homozygous rams were used. Severe selection mimics then the proposed eradication programme. Simulations were carried out with allelic frequencies and population parameters of existent rare breeds in The Netherlands. With severe selection all simulated breeds showed unacceptably high inbreeding rates (>0.5\% per year). For some breeds, moderate selection resulted in acceptable inbreeding rates, while for other breeds only mild selection resulted in acceptable rates. The frequency of the ARR allele after 5 years of selection was only slightly lower with moderate selection than with severe selection ( $0.8 \%$ lower on average), but it was clearly lower with mild selection. Based on these simulations, we propose a selection programme where with low frequencies of the ARR allele, mild selection is used initially. Once the ARR frequencies rise to a particular value, the switch can be made to moderate selection. The population size (e.g. below 750, 750 to 3750 and above 3750 ewes) determines the frequency of the ARR allele at which the switch can be made (33\%, 25\% and 10\%, respectively). With even higher ARR frequencies (above 70\%,50\% and 33\%, respectively) the regime can be changed to severe selection.
\end{abstract}

Keywords: control programmes, genetics, inbreeding, rare breeds, scrapie.

\section{Introduction}

Scrapie is a fatal infectious neurodegenerative disease for which susceptibility is associated with polymorphisms in the ovine prion protein $(\operatorname{Pr} P)$ gene. The polymorphisms occurring most frequently are those at codons $136(A / V), 154(R / H)$ and 171 $(Q / R / H)$, where each letter represents the amino acid coded at the indicated codon (Belt et al., 1995). The $V R Q$ allele is significantly associated with a high susceptibility to scrapie (Hunter et al., 1994), while the ARR allele is significantly associated with resistance to natural and experimental infections with scrapie and bovine spongiform encephalopathy (BSE) (Foster et al., 2001). In breeds where the VRQ allele is rare or absent, the wildtype $A R Q$ allele is associated with increased susceptibility to scrapie (Clouscard et al., 1995; Bossers et al., 1996; Drögemüller et al., 2001).

The Dutch scrapie eradication programme (the 'accelerated scrapie eradication programme 2002') is based on these genetic susceptibility variants. The goal is to eliminate scrapie by selecting for the ARR/ $A R R$ genotype. The programme was brought into action as a precautionary measure because the presence of BSE in the sheep population can not currently be excluded (Bruce et al., 2002). The programme indicates the obligatory and exclusive use of $A R R / A R R$ breeding and multiplier sires by the end of 2004 (Vellema, 2002). An important 
provision is that additional inbreeding due to $A R R /$ $A R R$ selection will remain acceptable.

Inbreeding occurs when two related animals produce offspring (Falconer and Mackay, 1996) and generally has negative effects (Hedrick and Kalinowski, 2000). Reported effects include reduced growth, reduced milk production, increased susceptibility to diseases and increased occurrence of congenital defects. Congenital defects are already present in the Veluws Heideschaap breed and they dramatically increased following a population bottleneck during the outbreak of the foot and mouth disease in The Netherlands (G. Pastink, personal communication). Inbreeding also leads directly to a reduction in genetic variation (Wiener et al., 1992) which reduces the effect of selection, either artificial selection for production traits or natural selection for adaptation to the (changing) environment (Lynch and Walsh, 1998). In the common Texel sheep breed, breeding values for weight at 135 days have been found to be slightly lower for $A R R / A R R$ rams than for non- $A R R /$ $A R R$ rams and breeding values for number of lambs born have been found to be slightly higher for $A R R$ / $A R R$ rams than for non- $A R R / A R R$ rams (Brandsma et al., 2004). In small breeds, larger effects are expected due to genetic drift. It is thus essential that inbreeding should be kept to a minimum. However, small population sizes and high selection pressure leads to an increase in inbreeding (Meuwissen and Woolliams, 1994). The guidelines of Food and Agriculture Organization (FAO) for the management of small populations recommend that the rate of inbreeding per generation $(\Delta \mathrm{F})$ should be below $1 \%$ (FAO, 1998).

In this paper the effect on inbreeding levels of selection on scrapie genotypes was analysed by computer simulation for several rare Dutch sheep breeds.

\section{Material and methods Populations}

Data of existing populations were used to simulate selection on scrapie genotypes. With this purpose, data on eight breeds with small population size $(<5000$ animals $)$ were assembled. Animals within these breeds had been genotyped by the Taqmanmethod. This method screens for three mutually exclusive allelic variants $A R R, A H Q$ and $V R Q$, while all other alleles are called $A R Q^{*}$. $A R Q^{*}$ includes predominantly the wildtype $A R Q$, but will also contain all other alleles not specifically screened for, including $A R H$ (Bossers et al., 1999). The genotype data were obtained from the Dutch Animal Health Service database. Information on population structure was also extracted from this database, supplemented with information from breeding organizations where necessary.

\section{Simulations}

Simulations were used to predict inbreeding levels and allele frequencies across years of selection against susceptible alleles. Populations were set up with the same structure as the breeds. Population size, sex ratio (Table 1), and composition of age groups (Table 2) in the breeding season 2002/2003 were used to form the initial generation. Each individual received two $\operatorname{Pr} P$ alleles $(A R R, A H Q$, $A R Q^{*}$ or $\left.V R Q\right)$, with probabilities determined by the allele frequencies in 2002/2003 (Table 1). All animals were assumed to be unrelated in the starting generation. All breeds had one breeding season per year. Ewes to produce litters for the next breeding season were selected at random from the ewes present in the population. Consequently, at each breeding season, ewes of different ages produced litters (i.e. generations overlapped). Each year the number of ewes selected was the same as the number of litters in the breeding season 2002/2003. Litter size was one or two with probabilities determined by the

Table 1 Breeds and population parameters used in the simulations (population parameters are based on the breeding season 2002/2003 at the start of the control programme)

\begin{tabular}{|c|c|c|c|c|c|c|c|c|c|c|}
\hline \multirow[t]{2}{*}{ Breed } & \multirow{2}{*}{$\begin{array}{l}\text { No. } \\
\text { of } \\
\text { ewes }\end{array}$} & \multirow{2}{*}{$\begin{array}{l}\text { No. } \\
\text { of } \\
\text { rams }\end{array}$} & \multirow{2}{*}{$\begin{array}{l}\text { Mean no. } \\
\text { ewes per } \\
\text { ram }\end{array}$} & \multirow{2}{*}{$\begin{array}{l}\text { Max. no. } \\
\text { ewes per } \\
\text { ram }\end{array}$} & \multirow{2}{*}{$\begin{array}{l}\text { No. lambs } \\
\text { per ewe }\end{array}$} & \multirow{2}{*}{$\begin{array}{c}\text { No. litters } \\
\text { per year }\end{array}$} & \multicolumn{4}{|c|}{ Allele frequencies } \\
\hline & & & & & & & $A R R$ & $A H Q$ & $A R Q^{*}$ & $V R Q$ \\
\hline Skudde & 350 & 300 & 10 & 50 & 1.37 & 150 & $0 \cdot 171$ & $0 \cdot 150$ & 0.679 & 0.000 \\
\hline Schoonebeeker & 450 & 300 & 8 & 75 & $1 \cdot 30$ & 180 & 0.064 & 0.016 & 0.743 & 0.029 \\
\hline Veluws Heideschaap & 1100 & 250 & 40 & 100 & 1.34 & 190 & 0.132 & $0 \cdot 031$ & $0 \cdot 816$ & 0.049 \\
\hline Mergellander & 1550 & 200 & 12 & 75 & 1.48 & 375 & 0.251 & $0 \cdot 000$ & 0.693 & 0.056 \\
\hline Kempisch Heideschaap & 1900 & 200 & 50 & 120 & 1.29 & 300 & 0.267 & $0 \cdot 010$ & $0 \cdot 711$ & 0.021 \\
\hline Drents Heideschaap & 2200 & 300 & 12 & 75 & 1.36 & 225 & 0.128 & 0.038 & 0.750 & 0.084 \\
\hline Hampshire Down & 2215 & 900 & 8 & 75 & 1.38 & 600 & 0.712 & $0 \cdot 000$ & $0 \cdot 284$ & 0.004 \\
\hline Fries Melkschaap & 3750 & 500 & 11 & 100 & 1.49 & 675 & $0 \cdot 102$ & 0.050 & $0 \cdot 848$ & 0.000 \\
\hline
\end{tabular}


Table 2 Age composition of the breeds, expressed as percentage of rams and percentage of ewes in each age class

\begin{tabular}{|c|c|c|c|c|c|c|c|c|c|c|}
\hline \multirow[b]{2}{*}{ Breed } & \multicolumn{5}{|c|}{ Age of rams (years) } & \multicolumn{5}{|c|}{ Age of ewes (years) } \\
\hline & 1 & 2 & 3 & 4 & $>5$ & 1 & 2 & 3 & 4 & $>5$ \\
\hline Skudde & 35 & 34 & 17 & 10 & 0 & 36 & 26 & 21 & 11 & 6 \\
\hline Schoonebeeker & 68 & 32 & 0 & 0 & 0 & 38 & 23 & 9 & 9 & 21 \\
\hline Veluws Heideschaap & 68 & 32 & 0 & 0 & 0 & 44 & 26 & 12 & 11 & 7 \\
\hline Mergellander & 69 & 31 & 0 & 0 & 0 & 42 & 25 & 11 & 10 & 12 \\
\hline Kempisch Heideschaap & 68 & 32 & 0 & 0 & 0 & 40 & 23 & 10 & 10 & 17 \\
\hline Drents Heideschaap & 50 & 20 & 15 & 8 & 7 & 20 & 16 & 15 & 15 & 34 \\
\hline Hampshire Down & 44 & 13 & 12 & 8 & 23 & 20 & 17 & 17 & 13 & 33 \\
\hline Fries Melkschaap & 25 & 25 & 25 & 13 & 12 & 35 & 35 & 20 & 7 & 3 \\
\hline
\end{tabular}

frequencies in 2002/2003. The number of rams selected varied according to the selection regime (see below). Offspring received at random one of the two alleles of the father and at random one of the two alleles of the mother. Relationships of the offspring with all previously born animals and their inbreeding coefficients were computed using standard procedures (Lynch and Walsh, 1998, p. 763). Each year, the number of animals culled was the same as the number of animals born. The probability of being culled was determined by the age composition of the breed (Table 2).

\section{Selection regimes}

Three selection regimes were simulated:mild, moderate and severe. Under all regimes, selection took place by using rams with at least one $A R R$ allele to inseminate ewes. The regimes differed in to what extent the use of heterozygous rams was allowed. Under mild selection, no distinction was made between homozygous and heterozygous $A R R$ rams and both were used without preference. For each breed, the number of ewes inseminated each year was the same as in 2002. The number of rams used to inseminate ewes was also constant across years and it was determined by the parameters given in Table 1. Under moderate selection, homozygous $A R R$ rams were used preferentially. The number of ewes per ram was the same as with mild selection. When there were not enough homozygous $A R R$ rams to produce the target number of litters, heterozygous rams were also used. Under severe selection, only homozygous $A R R$ rams were used. Since there were fewer rams available, they generally had to inseminate more ewes than under mild and moderate selection. The number of ewes/ram was set to $80 \%$ of the maximum number of ewes inseminated by a single ram in 2002. When there were not enough homozygous rams to produce the target number of litters, fewer litters were produced. The severe selection scheme is the scheme followed in the Dutch scrapie eradication programme.
For each combination of breed and selection regime, 25 simulations with 5 years of selection were run, and the parameters reported are the average of the 25 runs. Since the initial relationships were set to zero, inbred individuals can only be born after the second round of selection. Each year $t$ (starting at $t=2$ ), the average inbreeding coefficient $\left(\mathrm{F}_{t}\right)$ was determined for individuals born in that year. The rate of inbreeding $(\Delta \mathrm{F})$ was determined each year by the equation $\Delta \mathrm{F}_{t}=\left(\mathrm{F}_{t}-\mathrm{F}_{t-1}\right) /\left(1-\mathrm{F}_{t-1}\right)$ (Falconer and Mackay, 1996). At $t=5$, the overall inbreeding rate over the 5 years was computed as $\Delta \mathrm{F}_{1-5}=1$ $\left(1-\mathrm{F}_{5}\right)^{1 / 4}$. Both the maximum $\Delta \mathrm{F}_{t}$ (generally $\Delta \mathrm{F}_{2}$ ) and $\Delta \mathrm{F}_{1-5}$ are reported. The maximum acceptable inbreeding rate was assumed to be $0.5 \%$, which is more conservative than the figure of $1.0 \%$ recommended by FAO (1998). This conservative limit is justified because our estimates may well underestimate the rates observed in real populations (see below). Allele frequencies are reported both after one round of selection and after four rounds. For the Schoonebeeker breed, simulations were run for 50 years in order to investigate the long-term effects of different breeding strategies.

\section{Extra simulations}

In the simulations described above, a number of assumptions were made that may lead to biased predicted inbreeding levels. Inbreeding levels at the starting generation were set to zero. This will generally influence only the average $\mathrm{F}$ and not $\Delta \mathrm{F}$ in subsequent years. The exception is when rams selected in the first round tend to be more related than unselected rams, which is not unlikely in the case of selection for (homozygous) $A R R$ rams. Extra simulations using actual relationships at the start of selection were run for the Fries Melkschaap breed. This breed was chosen because pedigree information was reasonably accurate (unlike other breeds where pedigree information was incomplete). 
A second assumption in the simulations was that all selected rams and ewes had the same probability of pairing with each other. In practice, the distribution of a breed over different flocks will lead to varying probabilities of pairing certain rams and ewes. If rams are used preferentially within their own flock they may be paired with more related ewes than expected with random pairing. Also, in practice, breeding schemes aim to reduce inbreeding by using rams of other flocks. We simulated the breeding schemes that are in operation for the Schoonebeker and the Veluws Heideschaap breeds. These breeds are kept in several large flocks. In the Schoonebeeker breed, a group of three flocks are involved in a joint breeding programme. In this programme each flock only uses rams from the other two flocks and the flock providing rams alternates between years. In the Veluws Heideschaap breed, all nine flocks are involved in a joint breeding programme. Here flock 1 uses rams from flock 2 , flock 2 uses rams from flock 3 , flock 3 uses rams from flock 4 and so on, and flock 9 uses rams from flock 1 .

\section{Results}

Under severe selection, all examined breeds, except the Hampshire Down breed, experienced a high rate of inbreeding (Table 3 ). When the average $\Delta \mathrm{F}_{1-5}$ was taken as the criterion for acceptable rates, then the Mergellander breed also showed rates below 0.5\%. However, the results in Table 3 are the average of 25 simulations. Thus there is roughly a $50 \%$ chance that the populations will have higher inbreeding rates than those indicated. In the Mergellander breed, $\Delta \mathrm{F}_{1-5}$ was above 0.5 in 11 of the 25 simulations, and the maximum $\Delta \mathrm{F}_{1-5}$ was $0.59 \%$. The inbreeding rate was generally highest at $t=2$ (Figure 1), especially for the rarer breeds. The average maximum $\Delta \mathrm{F}_{\mathrm{t}}$ with severe selection over all the breeds (except the Hampshire Down breed) was $1.22 \%$. The frequency of the $A R R$ allele in animals born after 5 years of severe selection was for all breeds above 0.65 and the average over breeds was 0.79. Excluding the breeds Drents Heideschaap and Hampshire Down, the frequency of $A R R / A R R$ animals in the whole population (i.e. the pool of selection candidates), after 5 years of

Table 3 Effects of different selection regimes on the rate of inbreeding and the frequency of the ARR allele after 5 years of selection $\dagger$

\begin{tabular}{|c|c|c|c|c|c|}
\hline Breed & $\begin{array}{l}\text { Selection } \\
\text { regime }\end{array}$ & $\begin{array}{l}\operatorname{Max}_{(\times 100)} \Delta \mathrm{F}_{t} \\
\end{array}$ & $\begin{array}{l}\Delta \mathrm{F}_{1-5} \\
(\times 100)\end{array}$ & $\begin{array}{l}\text { Freq. } A R R / A R R \\
\text { in population }\end{array}$ & $\begin{array}{c}\text { Freq. } A R R \text { in } \\
\text { new born animals }\end{array}$ \\
\hline \multirow[t]{3}{*}{ Skudde } & mild & $0.47(0.33-\mathbf{0 . 6 4})$ & $0 \cdot 38(0 \cdot 29-0 \cdot 50)$ & $0.219(0.196-0.246)$ & $0.468(0.421-0.500)$ \\
\hline & moderate & $0.66(0.39-1.39)$ & $0.45(0.31-0.69)$ & $0.502(0.449-0.568)$ & $0.822(0.780-0.888)$ \\
\hline & severe & $1.76(1.51-3.08)$ & $1.48(0.99-1.90)$ & $0.522(0.485-0.571)$ & $0.835(0.805-0.857)$ \\
\hline \multirow[t]{3}{*}{ Schoonebeeker } & mild & $0.66(0.33-0.99)$ & $0.46(0.29-0 \cdot 70)$ & $0.130(0.101-0.160)$ & $0.369(0.273-0.400)$ \\
\hline & moderate & $1.02(0.85-2.38)$ & $0.86(0.44-1.76)$ & $0.235(0.201-0.253)$ & $0.715(0.529-0.776)$ \\
\hline & severe & $2.21(1.65-2.75)$ & $1.27(0.70-1.89)$ & $0.245(0.211-0.263)$ & $0.720(0.554-0.806)$ \\
\hline \multirow[t]{3}{*}{ Veluws Heideschaap } & mild & $0.39(0.26-\mathbf{0} \cdot \mathbf{5 6})$ & $0.32(0.23-0.49)$ & $0 \cdot 298(0 \cdot 270-0 \cdot 318)$ & $0.563(0.538-0.588)$ \\
\hline & moderate & $0.95(0.64-2.29)$ & $0.70(0.42-1.56)$ & $0.406(0.368-0.436)$ & $0.801(0.766-0.832)$ \\
\hline & severe & $1.62(0.98-3.06)$ & $1.22(0.76-2.17)$ & $0.415(0.392-0.429)$ & $0.807(0.783-0.824)$ \\
\hline \multirow[t]{3}{*}{ Mergellander } & mild & $0.25(0.19-0.31)$ & $0.16(0.13-0.21)$ & $0.284(0.258-0.308)$ & $0.523(0.480-0.567)$ \\
\hline & moderate & $0.30(0.23-0.67)$ & $0 \cdot 21(0 \cdot 16-0.25)$ & $0 \cdot 402(0 \cdot 381-0 \cdot 423)$ & $0.778(0.755-0.803)$ \\
\hline & severe & $0.51(0.40-0.86)$ & $0.45(0.33-0.59)$ & $0.406(0 \cdot 384-0.430)$ & $0.782(0.766-0.832)$ \\
\hline \multirow[t]{3}{*}{ Kempisch Heideschaap } & mild & $0.35(0.27-0.56)$ & $0.28(0.21-0.49)$ & $0 \cdot 277(0 \cdot 247-0 \cdot 301)$ & $0.563(0.539-0.590)$ \\
\hline & moderate & $0 \cdot 48(0 \cdot 46-0 \cdot 76)$ & $0.41(0.31-0.57)$ & $0 \cdot 340(0 \cdot 319-0 \cdot 358)$ & $0.812(0.770-0.838)$ \\
\hline & severe & $0.93(0.78-1.60)$ & $0.89(0.62-1.29)$ & $0 \cdot 342(0 \cdot 322-0 \cdot 361)$ & $0.816(0.779-0.837)$ \\
\hline \multirow[t]{3}{*}{ Drents Heideschaap } & mild & $0.16(0.12-0 \cdot 20)$ & $0.12(0.09-0 \cdot 16)$ & $0.062(0.054-0.088)$ & $0.426(0.338-0.564)$ \\
\hline & moderate & $0.33(0.26-0.57)$ & $0.24(0.13-0.42)$ & $0.100(0.094-0.108)$ & $0.663(0.640-0.695)$ \\
\hline & severe & $0.73(0.55-1.45)$ & $0.55(0.36-0.93)$ & $0 \cdot 111(0 \cdot 108-0 \cdot 127)$ & $0.661(0.628-0.702)$ \\
\hline \multirow[t]{3}{*}{ Hampshire Down } & mild & $0.03(0.01-0.09)$ & $0.02(0.00-0.07)$ & $0.564(0.515-0.600)$ & $0.758(0.732-0.784)$ \\
\hline & moderate & $0 \cdot 10(0 \cdot 06-0 \cdot 15)$ & $0.05(0.03-0.10)$ & $0.712(0.690-0.733)$ & $0.912(0.889-0.930)$ \\
\hline & severe & $0 \cdot 10(0 \cdot 06-0 \cdot 15)$ & $0.05(0.03-0 \cdot 10)$ & $0.712(0 \cdot 690-0.733)$ & $0.912(0.889-0.930)$ \\
\hline \multirow[t]{3}{*}{ Fries Melkschaap } & mild & $0 \cdot 10(0.06-0 \cdot 15)$ & $0.07(0.04-0.10)$ & $0.139(0.119-0.159)$ & $0.476(0.407-0.544)$ \\
\hline & moderate & $0.30(0.20-0.57)$ & $0.20(0.14-0 \cdot 27)$ & $0.235(0.201-0.253)$ & $0.781(0.747-0.799)$ \\
\hline & severe & $0.77(0.64-1.37)$ & $0.58(0.38-0.99)$ & $0.262(0.247-0.272)$ & $0.801(0.787-0.820)$ \\
\hline
\end{tabular}

+ Selection regimes: severe selection = exclusive use of $A R R / A R R$ rams, moderate selection $=$ use of $A R R / A R R$ rams supplemented with $A R R / \mathrm{X}$ rams if not enough $A R R / A R R$ rams are available, mild selection = use of both $A R R / A R R$ and $A R R /$ $\mathrm{X}$ rams indiscriminately. Max. $\Delta \mathrm{F}_{t}=$ maximum rate of inbreeding $(X 100)$ per year, $\Delta \mathrm{F}_{1-5}=$ rate of inbreeding $(X 100)$ over 5 years. Numbers in bold indicate unacceptably high $(>0.5 \%)$ inbreeding rates. Freq. $A R R / A R R$ in population $=$ frequency of homozygous $A R R$ animals in the whole population after 5 years of selection. Freq. $A R R$ in new born animals: allelic frequency of $A R R$ for animals born in the last year. Numbers in brackets indicate the maximum and the minimum over replicates. 
selection ranged from 0.25 to 0.52 . The Drents Heideschaap breed had a lower frequency $(0 \cdot 11)$ because animals tend to remain longer in the population than in other breeds. The Hampshire Down breed had a higher frequency (0.71) because of its high initial $A R R$ frequency.

With moderate selection, the frequency of the ARR allele after 5 years of selection was on average only 0.008 below the frequency under severe selection. Initially, $A R R$ frequencies were higher with severe selection, but moderate selection tended to catch up

(a)

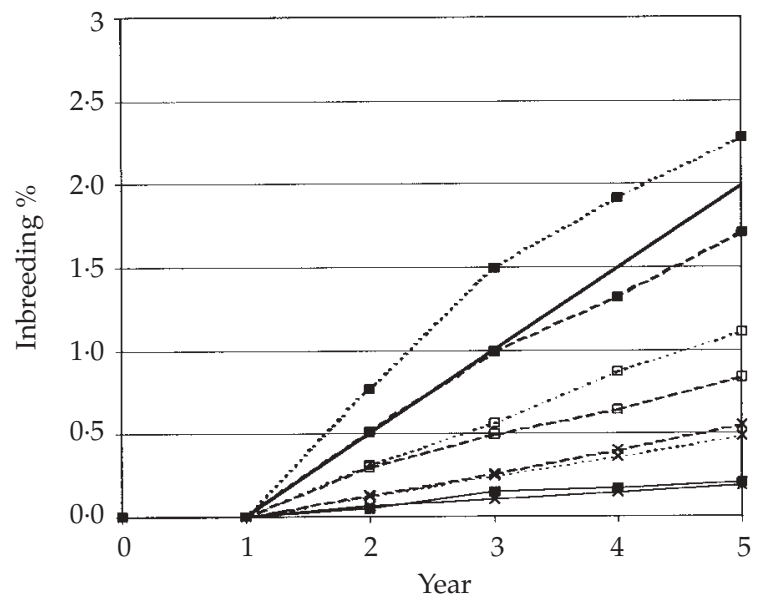

(c)

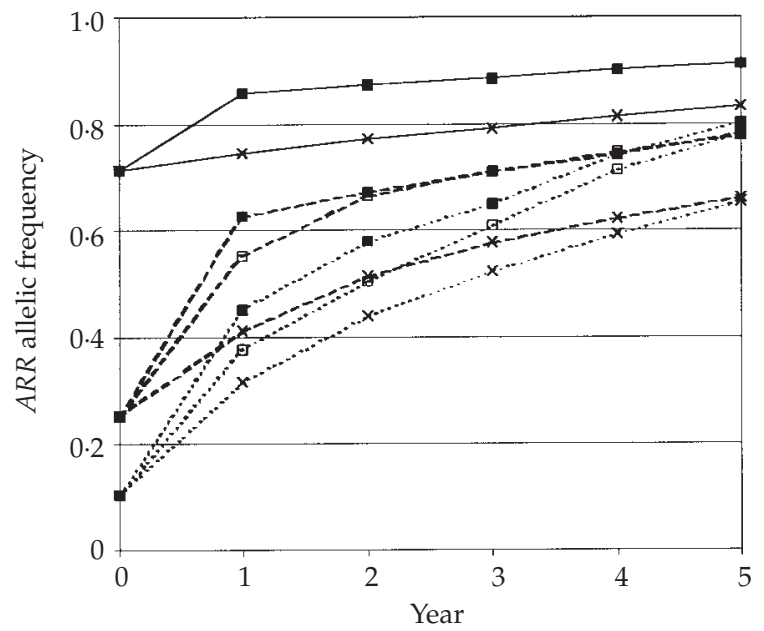

after the 2nd year (Figure 1). This is because the difference between severe and moderate selection is only that with the latter, $A R R / A R R$ rams are supplemented with heterozygous $A R R / \mathrm{X}$ rams if the number of $A R R / A R R$ rams is insufficient. Thus if the frequency of $A R R$ is high, the two regimes converge. This is why in the Hampshire Down breed (with its high initial $A R R$ frequency) no difference between moderate and severe selection was found. $\Delta \mathrm{F}$ was considerably lower with moderate selection than with severe selection. This is because, in contrast with severe selection, moderate selection does not

(b)

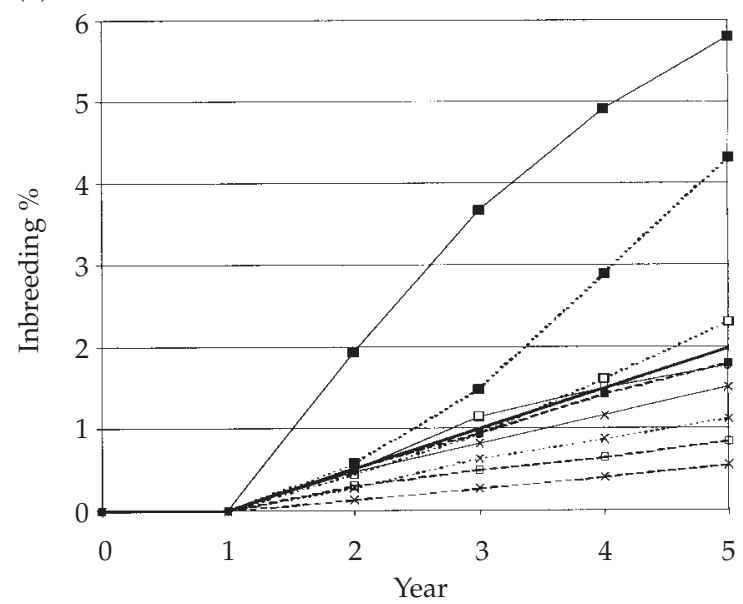

(d)

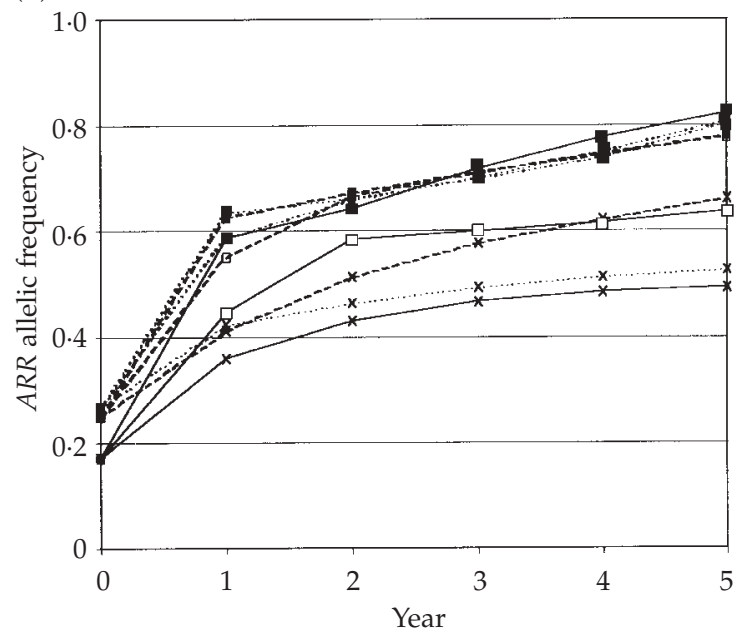

Figure 1 Inbreeding levels ((a) and(b)) and frequency of the $A R R$ allele in new born animals ((c) and (d)) for three breeds differing in ARR frequency in the base generation ((a) and (c)) [Fries Melkschaap (0.10), Mergellander (0.25) and Hampshire Down (0.71)], and for three breeds differing in population size (b) and (d)) [Skudde (650), Mergellander (1750) and Kempisch Heideschaap (2100)]. Each breed is shown under three selection regimes: severe $\mathbf{\square}$, moderate $\square$ and mild $\times$. Thick lines indicate an inbreeding rate of $0.5 \%$ per year (acceptable). 
Table 4 Effects of different selection regimes on the rate of inbreeding and the frequency of the ARR allele after 5 years of selection, assuming that an inbreeding restriction is in operation (Schoonebeeker and Veluws Heideschaap breeds) or that animals at the start of selection are not unrelated (Fries Melkschaap breed)†

\begin{tabular}{|c|c|c|c|c|c|}
\hline Breed & $\begin{array}{l}\text { Selection } \\
\text { regime }\end{array}$ & $\underset{(\times 100)}{\operatorname{Max} . \Delta \mathrm{F}_{t}}$ & $\begin{array}{l}\Delta \mathrm{F}_{1-5} \\
(\times 100)\end{array}$ & $\begin{array}{l}\text { Freq. } A R R / A R R \\
\text { in population }\end{array}$ & $\begin{array}{c}\text { Freq. } A R R \text { in } \\
\text { new born animals }\end{array}$ \\
\hline \multirow{3}{*}{ Schoonebeeker } & mild & $0.33(0.21-0.93)$ & $0.23(0.15-0.33)$ & $0.118(0.088-0.162)$ & $0.361(0.333-0.390)$ \\
\hline & moderate & $0.65(0.34-1.06)$ & $0.37(0.27-0.51)$ & $0.249(0.197-0.326)$ & $0.531(0.494-0.601)$ \\
\hline & severe & $2.07(1.09-4.61)$ & $0.99(0.62-1.51)$ & $0.326(0.252-0.393)$ & $0.599(0.533-0.665)$ \\
\hline \multirow[t]{3}{*}{ Veluws Heideschaap } & mild & $0.15(0.04-0.37)$ & $0.09(0.02-0.14)$ & $0.075(0.060-0.091)$ & $0.342(0.313-0.387)$ \\
\hline & moderate & $0.37(0.16-0.44)$ & $0.24(0.07-0.32)$ & $0.157(0.139-0.172)$ & $0.441(0.398-0.487)$ \\
\hline & severe & $0.43(0.21-0.63)$ & $0.36(0.13-0.42)$ & $0.166(0.146-0.186)$ & $0.469(0.421-0.512)$ \\
\hline \multirow[t]{3}{*}{ Fries Melkschaap } & mild & $0.17(0.12-0.33)$ & $0.12(0.08-0.25)$ & $0.139(0.119-0.159)$ & $0.476(0.407-0.544)$ \\
\hline & moderate & $0.42(0.31-0.72)$ & $0.30(0.24-0.68)$ & $0.235(0.201-0.253)$ & $0.781(0.747-0.799)$ \\
\hline & severe & $1.56(1.32-6.06)$ & $1.04(0.85-2.01)$ & $0.262(0.247-0.272)$ & $0.801(0.787-0.820)$ \\
\hline
\end{tabular}

+ See Table 3.

rely on a single or a few $A R R / A R R$ rams in the first generations of selection. The three rarest breeds (Skudde, Schoonebeeker and Veluws Heideschaap) still showed $\Delta \mathrm{F}$ values above $0.5 \%$ with moderate selection. Under mild selection, $\Delta \mathrm{F}_{1-5}$ was still lower, but then $A R R$ frequencies clearly dropped. For the Schoonebeeker breed and for the Skudde and Kempisch Heideschaap breeds in some cases, the maximum $\Delta \mathrm{F}_{t}$ remained on average above $0.5 \%$ even under mild selection.

Population decline occurred for most breeds under severe selection because not enough $A R R / A R R$ rams were available to inseminate all ewes. The decline was absent in the Hampshire Down breed because of its high initial $A R R$ frequency. For the Skudde and Drents Heideschaap breeds, declines were rare (observed in less than four of the 25 simulations) and small (less than 20\%). For the other breeds, except the Schoonebeeker breed, the population decline was on average between $10 \%$ and $20 \%$. Population declines were observed only in the first year of selection, after which the population fully recovered. No population decline occurred for these breeds with mild selection. For the Schoonebeeker breed, a more serious decline was observed. Under severe selection, a reduction of on average $69.3 \%$ occurred and in four of the 25 simulations no ARR/ARR rams were available after 1 year of selection. Under mild selection, the population decline was on average $4.7 \%$.

For the two breeds for which an inbreeding restriction is in operation (Schoonebeeker and Veluws Heideschaap), the different selection regimes were also evaluated while keeping the current breeding structure in place as much as possible. The result was that both the inbreeding levels and the $A R R$ frequencies decreased compared with simulations without the inbreeding restriction (Table 4). Both $\Delta \mathrm{F}_{1-5}$ and maximum $\Delta \mathrm{F}_{t}$ values for the
Schoonebeeker breed were on average below $0.5 \%$ for mild selection. For some simulations, $\Delta \mathrm{F}_{t}$ reached values above $0.5 \%$. For the Veluws Heideschaap breed, $\Delta \mathrm{F}$ values remained below $0.5 \%$ for all selection regimes, except in a few simulations under severe selection, where maximum $\Delta \mathrm{F}_{t}$ reached $0.63 \%$.

The results for the Schoonebeeker breed over 50 years of selection are shown in Figure 2 in more detail. The main difference between the different selection regimes occurred in the first few years of selection. Especially under severe selection there was a strong increase in inbreeding in the first 3 years. After the initial increase, selection regimes had an inbreeding rate in later years $(t>10)$ comparable with that with no selection (e.g. the slope of the lines was about the same). This is because by the time the $A R R$-frequency is high, selection for the $A R R$-allele starts to resemble random culling of animals. The stronger the selection was, the more variable the inbreeding rate was. An exception was with mild selection in later years where the rate of inbreeding was slightly more variable than with moderate selection. As expected, severe selection reached high $A R R$ frequencies earlier than the other selection regimes, although the difference from that with moderate selection was minimal. The average time until fixation was 31.5 years with severe selection and 32.4 years with moderate selection. With mild selection, $A R R$ frequencies were more variable and did not reach fixation within the 50 years of selection. A combination of mild selection in the first years and moderate to severe selection in later years seems to be a sensible strategy to apply in practice. One could start with moderate selection, but some simulations showed high $\Delta \mathrm{F}_{t}$ in the initial years (up to $0.93 \%$ ), which were avoided when mild selection was used in the first 3 years. One also has to follow the inbreeding restriction regime strictly as any breach will increase inbreeding levels. Thus in order to be 
(a)

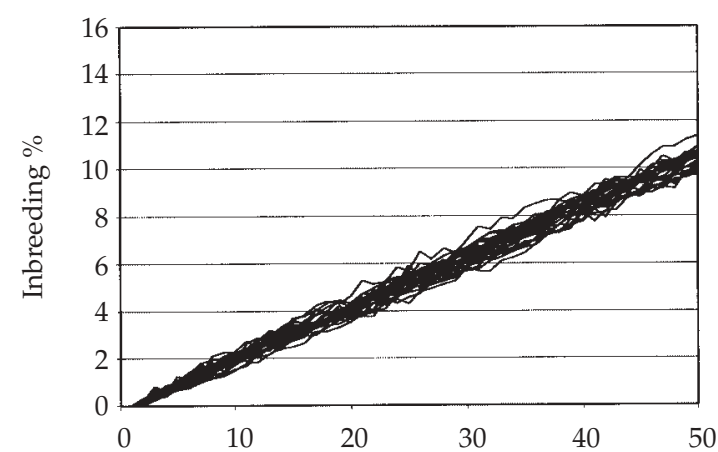

(c)

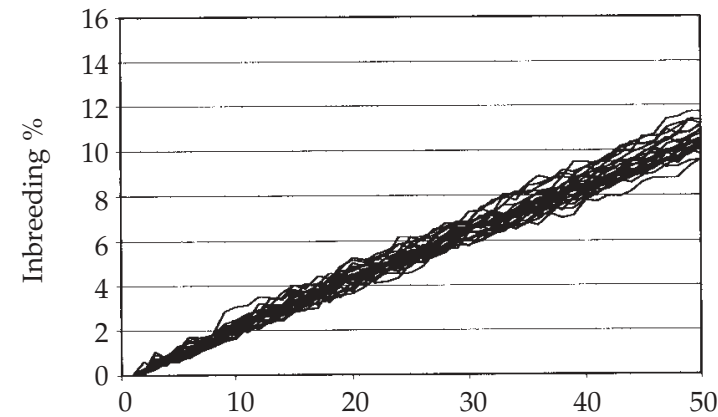

(e)

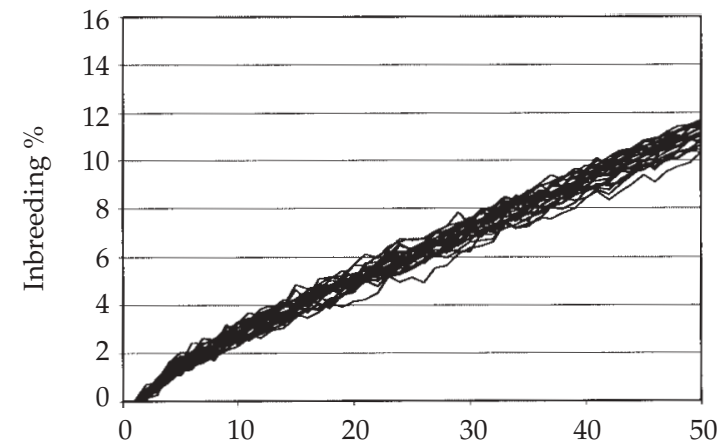

(g)

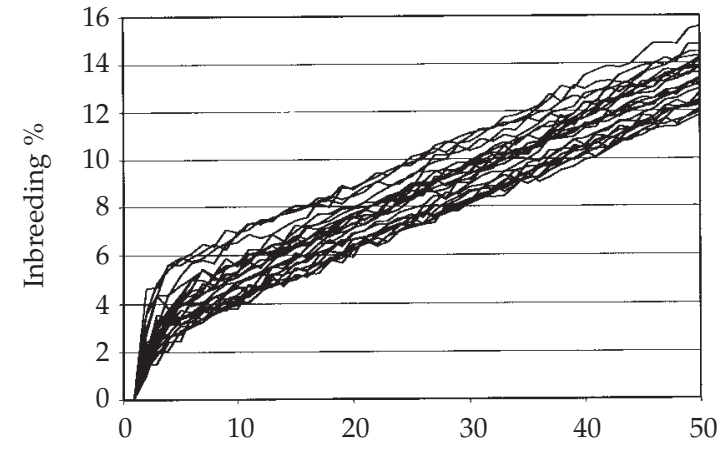

(b)

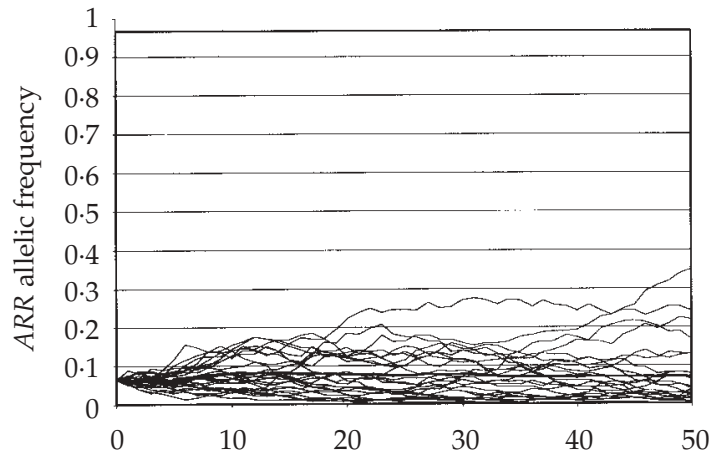

(d)

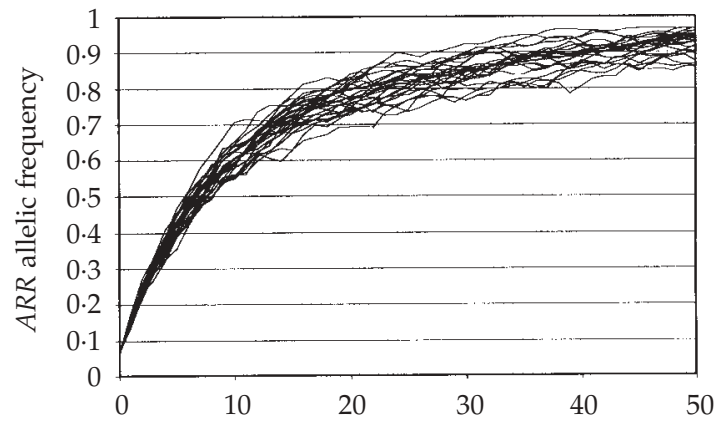

(f)

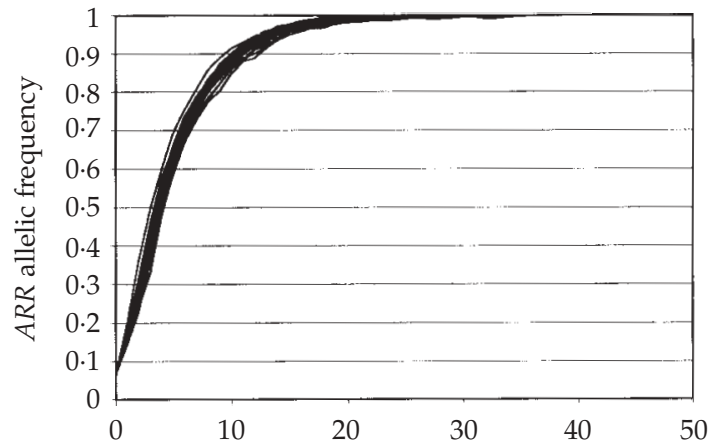

(h)

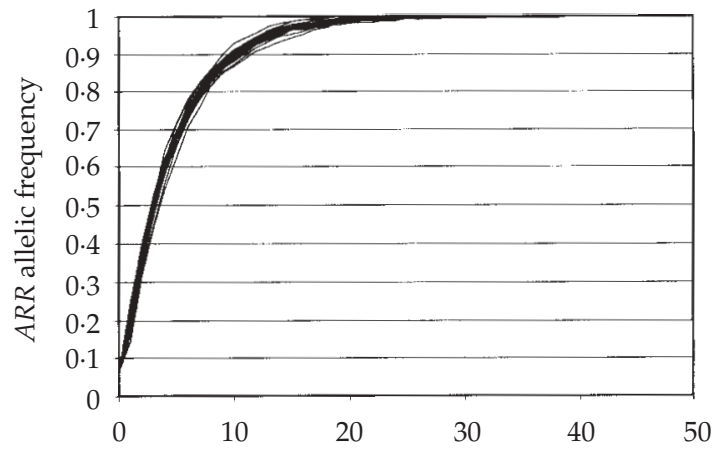

Figure 2 Inbreeding levels ((a), (c), (e) and (g)) and frequency of the ARR allele in new born animals (b), (d), (f) and (h)) for the Schoonebeeker breed over 50 years of selection. (a), (b): no selection; (c), (d): mild selection (both heterozygous and homozygous ARR rams used), (e), (f): moderate selection (preferential use of homozygous ARR rams), (g), (h): severe selection (exclusive use of $A R R$ rams). Each line represents results from one simulation. 
Table 5 Average co-ancestry of animals with and without ARR alleles in 2003 for the Fries Melkschaap breed (ARR/ $\mathrm{ARR}=$ homozygous $\mathrm{ARR}$ animals $\mathrm{ARR} / \mathrm{X}=$ heterozygous $\mathrm{ARR}$ animals, $\mathrm{X} / \mathrm{X}=$ animals without $\mathrm{ARR}$ alleles)

\begin{tabular}{lccc}
\hline \hline & ARR/ARR & ARR/X & $X / X$ \\
\hline ARR/ARR & 0.1358 & & \\
ARR/X & 0.0366 & 0.0512 & \\
$X / X$ & 0.0003 & 0.0002 & 0.0077 \\
\hline \hline
\end{tabular}

on the safe side, mild selection seems the regime of choice to start with.

For the Fries Melkschaap breed, the effect of the degree of relationship between the animals at the start of the selection was also evaluated. Animals with $A R R$ alleles were more closely related to each other than animals without ARR alleles (Table 5). All animals with $A R R$ alleles could be traced back to three ancestors about six generations ago. The high relationship between $A R R / A R R$ animals has consequences for the inbreeding levels, especially under the severe selection regime. When compared with simulations that did not take initial relationships into account, $\Delta \mathrm{F}$ almost doubled to, on average, $1.04 \%$ after the first 5 years of selection (maximum $1.56 \%$ ) with severe selection. With mild and moderate selection, the $\Delta \mathrm{F}$ remained on average below $0.5 \%$ when initial relationships were taken into account.

General advice

The selection regime for eliminating scrapie susceptible alleles has to be based on population size and frequency of the $A R R$ allele in order to maintain inbreeding levels at an acceptable level. Based on the results in this paper we have set up a rule of thumb

Table 6 General advice to be used as a rule of thumb for which different selection regimes should be applied in order to maintain inbreeding levels and loss of genetic diversity at acceptable levelst

\begin{tabular}{llll}
\hline \hline \multirow{2}{*}{$\begin{array}{l}\text { No. of } \\
\text { ewes }\end{array}$} & \multicolumn{3}{c}{ Advised selection regime } \\
\cline { 2 - 4 } & \multicolumn{1}{c}{ Mild } & \multicolumn{1}{c}{ Moderate } & Severe \\
\hline$<750$ & $<0.33(<10 \%)$ & $0.33-0.70(10-50 \%)$ & $>0 \cdot 70(>50 \%)$ \\
$751-3750$ & $<0.25(<5 \%)$ & $0 \cdot 25-0.50(5-25 \%)$ & $>0 \cdot 50(>25 \%)$ \\
$\geq 3751$ & $<0.10(<1 \%)$ & $0 \cdot 10-0.33(1-1 \%)$ & $>0 \cdot 33(>10 \%)$ \\
\hline \hline
\end{tabular}

t The table shows allele frequencies and approximate frequencies of homozygous $A R R / A R R$ rams (in\% in brackets) at which a particular selection regime should be followed. Severe selection $=$ exclusive use of $A R R / A R R$ rams, moderate selection = use of $A R R / A R R$ rams supplemented with $A R R /$ $\mathrm{X}$ rams if not enough $A R R / A R R$ rams are available, mild selection $=$ use of both $A R R / A R R$ and $A R R / \mathrm{X}$ rams indiscriminately. that can be used to decide which selection regime to use (Table 6). This advice had to be simple and easy to use in practice. Hence, breeds were divided into three categories based on the number of ewes. The two rarest breeds (Skudde and Schoonebeeker) had clearly higher inbreeding rates than the other breeds (see Tables 3 and 4 and Figure 1). Based on the number of ewes in their populations, a value of 750 ewes was set up as the lower threshold. The higher threshold was set up at 3750 ewes (five times the lower threshold which is about the number of ewes in the Fries Melkschaap breed) based on the fact that with moderate selection a few simulations for the Fries Melkschaap breed showed a maximum inbreeding rate of just above $0.5 \%$ (i.e. it is at a switching point between mild and moderate selection).

Breeds were also divided into three categories based on their $A R R$ frequencies. For the larger breeds $(>3750)$ the Fries Melkschaap was used again to set the threshold for choosing between mild and moderate selection. This resulted in a threshold at an $A R R$ frequency of $0 \cdot 10$. The threshold for choosing between moderate and severe selection was set up to achieve a pool of potential rams for siring the next year's lambs of about 75 rams or more. For a breed with 3750 ewes and 750 rams (the number of rams is on average about $20 \%$ the number of ewes), this means that the frequency of $A R R / A R R$ rams has to be at least 0.10 before severe selection can be applied, and this corresponds to an $A R R$ frequency of about 0.33 . When applied to a breed of 750 ewes, the same reasoning leads to a 0.50 frequency of $A R R / A R R$ rams, corresponding to an $A R R$ frequency of about $0 \cdot 70$. With mild selection, both homozygous and heterozygous rams are used. A frequency of 0.50 rams, needed for a population with 150 rams, with at least one $A R R$ allele corresponds to a frequency of 0.70 non- $A R R$ alleles and to a frequency of $0.09 A R R /$ $A R R$ animals. The frequency of $A R R / A R R$ rams for choosing between mild and moderate selection for the smallest population size was therefore set to $0 \cdot 10$. The thresholds for populations between 750 and 3750 ewes were set about halfway between the thresholds for smaller and larger populations, leading to the advice given in Table 6 .

Following the advice in Table 6, the selection regime will change when the ARR frequencies increase due to selection. Such a dynamic selection strategy has the advantage that when the $A R R$ frequencies increase more slowly (or more quickly) than expected, the selection regime changes accordingly, thus avoiding unexpectedly high inbreeding rates. The results of this strategy are depicted for the Schoonebeeker in Figure 3. It can be seen that the 

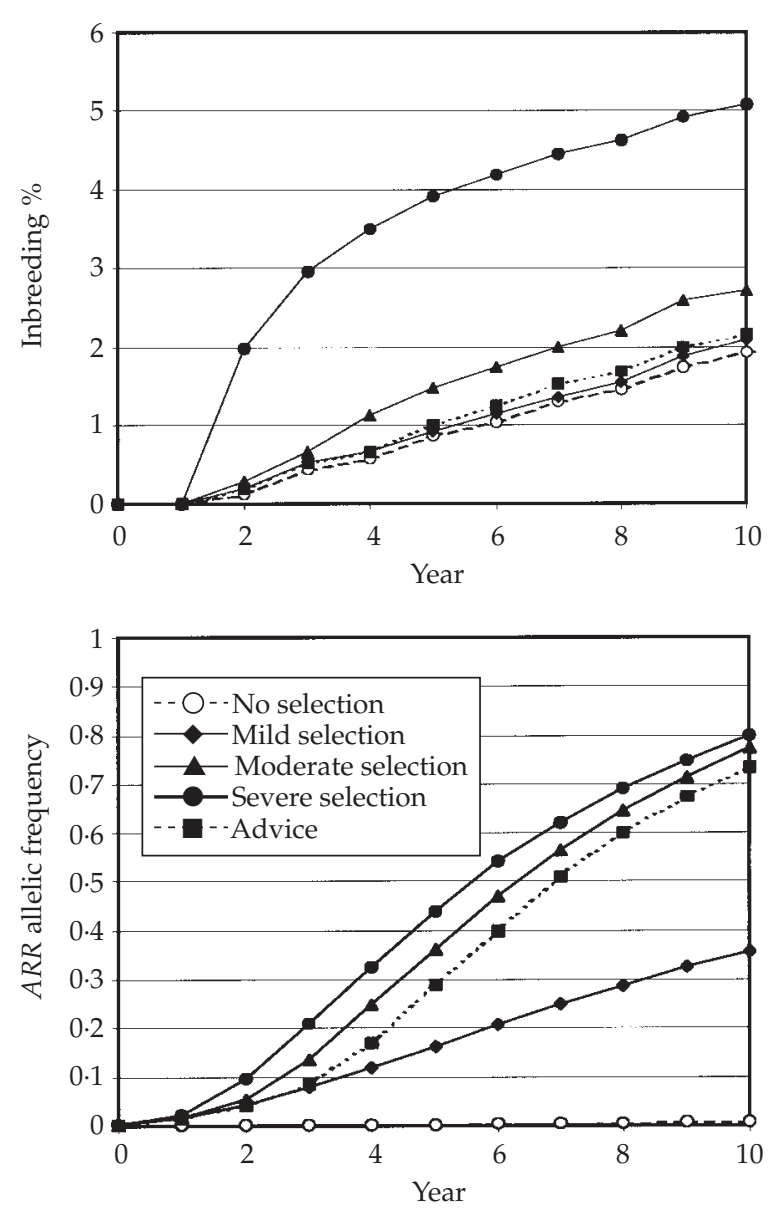

Figure 3 Effect of different selection regimes on (a) inbreeding levels and (b) frequency of the ARR allele for the Schoonebeeker breed. With selection following the advice (see Table 6), the regime is changed depending on the frequencies of the $A R R$ allele.

increase in inbreeding with this strategy is only small, compared with the situation without selection. The frequency of the $A R R$ allele is, however, only slightly less than under severe selection after 10 years of selection. With this strategy, fixation of the $A R R$ allele was reached after on average 36.8 years compared with 31.5 and 32.4 years with a fixed severe and moderate selection, respectively.

\section{Discussion}

The effects of breeding for scrapie resistance on inbreeding can be severe. For all rare breeds examined in this paper, except the Hampshire Down breed, severe selection (exclusive use of homozygous $A R R$ rams) produces inbreeding rates above $0.5 \%$ per year. Moreover, most breeds will also suffer a population decline under severe selection because there are not enough homozygous $A R R$ rams available to inseminate all ewes. These two effects combined would increase the probability of extinction of these rare breeds to unacceptably high levels.

The inbreeding levels predicted in this paper probably underpredict real values. In breeds with low frequencies of the $A R R$ allele it is likely that the alleles originate from one or few common ancestors. Selection for the ARR alleles will then lead to even higher inbreeding levels than those indicated here, because equal co-ancestries between all animals (whether having ARR alleles or not) were simulated. Indeed the one breed for which we had a reliable pedigree, the Fries Melkschaap, showed that inbreeding levels were almost doubled when relationships were taken into account. It is likely that in other breeds with low $A R R$ frequencies, animals having one or two $A R R$ alleles will also have common ancestors. Indeed for the Mergellander breed it is suspected that all $A R R$ alleles originate from a single ram (W. de Haan, personal communication).

All selected sires were assumed to produce the same number of offspring. However, this will not be generally the case as differences in fertility may exist and some rams may be used preferentially. This can lead to higher inbreeding levels, if the offspring of a preferred ram also produces more offspring. One may, however, also use variable numbers of offspring to its advantage, by increasing the number of offspring of rams that show a low average relationship to the rest of the population. The optimized contribution algorithm (Meuwissen, 1997) follows this approach, and at the same time optimizes selection. Sonesson et al. (2003) evaluated this approach for the elimination of single gene genetic defects. Provided that a reliable pedigree is present, optimal contribution will accelerate the increase of the $A R R$ allele at the same or a lower rate of inbreeding than that obtained following the advice of this paper.

Scrapie eradication programmes are being set up all over Europe (e.g. Barillet et al., 2002; Detwiler and Baylis, 2003). PrP genotype frequencies have been assessed in a large number of breeds (e.g. Bossers et al., 1999; Drögemüller et al., 2001; O'Doherty et al., 2002; Palhière et al., 2002) and strategies for scrapie eradication in large commercial breeds have been modelled (Kao et al., 2001; Arnold et al., 2002; Sonesson et al., 2003). Our research shows that, in rare breeds, attention to inbreeding is of vital importance. If the most straightforward selection 
strategy (i.e. exclusive use of homozygous $A R R$ rams) is rigidly implemented these breeds will suffer the risk of extinction. A more careful selection strategy that initially allows the use of heterozygous $A R R$ rams as well, will avoid unacceptably high inbreeding levels and lead to the same levels of resistant sheep, albeit some years later. At the same time, the loss of genetic diversity within breeds through genetic drift caused by selection of a few individuals can be also avoided.

\section{Acknowledgements}

Thanks to Albert Visscher, Anna Sonesson, Miranda van Eckeveld and Luc Janss who initiated this research. Beatriz Villenueva and an anonymous reviewer helped with numerous comments. We are also grateful to Piet Vellema who co-ordinated the input of the Dutch Animal Health Service and commented on a previous version of the manuscript. E. Brandsma (Skudde), G. Pastink (Veluws Heideschaap), W. de Haan (Mergellander) and T. Meerman (Schoonebeeker and Drents Heideschaap) provided additional information for various breeds.

\section{References}

Arnold, M., Meek, C., Webb, C. R. and Hoinville, L. J. 2002. Assessing the efficacy of a ram-genotyping programme to reduce susceptibility to scrapie in Great Britain. Preventive Veterinary Medicine 56: 227-249.

Barillet, F., Andreoletti, O., Palhière, I., Aguerre, X., Arranz, J. M., Minery, S., Soulas, C., Belloc, J. P., Briois, M., Frégeat, G., Teinturier, P., Amigues, Y., Astruc, J. M., Boscher, M. Y. and Schelcher, F. 2002. Breeding for scrapie resistance using PrP genotyping in the French dairy sheep breeds. Proceedings of the seventh world congress on genetics applied to livestock production, Montpellier, CD-ROM communication no. 13-20.

Belt, P. B. G. M., Muileman, I. H., Schreuder, B. E. C., BosDe Ruijter, J., Gielkens, A. L. J. and Smits, M. A. 1995. Identification of 5 allelic variants of the sheep PrP gene and their association with natural scrapie. Journal of General Virology 76: 509-517.

Bossers, A., Harders, F. L. and Smits, M. A. 1999. PrP genotype frequencies of the most dominant sheep breed in a country free from scrapie. Archives of Virology 144: 829-834.

Bossers, A., Schreuder, B. E. C., Muileman, I. H., Belt, P. and Smits, M. A. 1996. PrP genotype contributes to determining survival times of sheep with natural scrapie. Journal of General Virology 77: 2669-2673.

Brandsma, J. H., Janss, L. L. G. and Visscher, A. H. 2004. Association between PrP genotypes and littersize and 135 days weight in Texel sheep. Livestock Production Science 85: 59-64.

Bruce, M. E., Boyle, A., Cousens, S., McConnell, I., Foster, J., Goldmann, W. and Fraser, H. 2002. Strain characterization of natural sheep scrapie and comparison with BSE. Journal of General Virology 83: 695-704.

Clouscard, C., Beaudry, P., Elsen, J. M., Milan, D., Dussaucy, M., Bounneau, C., Schelcher, F., Chatelain, J., Launay, J. M. and Laplanche, J. L. 1995. Different allelic effects of the codons 136 and 171 of the prion protein gene in sheep with natural scrapie. Journal of General Virology 76: 2097-2101.

Detwiler, L. A. and Baylis, M. 2003. The epidemiology of scrapie. Revue Scientifique et Technique-Office International des Épizooties 22: 121-143.

Drögemüller, C., Leeb, T. and Distl, O. 2001. Prp genotype frequencies in German breeding sheep and the potential to breed for resistance to scrapie. Veterinary Record 149: 349-352.

Falconer, D. S. and Mackay, T. F. C. 1996. Introduction to quantitative genetics. Longman, Harlow, Essex.

Food and Agriculture Organization. 1998. Secondary guidelines for the management of small populations at risk. FAO, Rome, Italy.

Foster, J. D., Parnham, D., Chong, A., Goldmann, W. and Hunter, N. 2001. Clinical signs, histopathology and genetics of experimental transmission of BSE and natural scrapie to sheep and goats. Veterinary Record 148: 165-171.

Hedrick, P. W. and Kalinowski, S. T. 2000. Inbreeding depression in conservation biology. Annual Review of Ecology and Systematics 31: 139-162.

Hunter, N., Goldmann, W., Smith, G. and Hope, J. 1994. The association of a codon $136 \mathrm{PrP}$ gene variant with the occurence of natural scrapie. Archives of Virology 137: 171-177.

Kao, R. R., Gravenor, M. B. and Mclean, A. R. 2001. Modelling the national scrapie eradication programme in the UK. Mathematical Bioscience 174: 61-76.

Lynch, M. and Walsh, B. 1998. Genetics and analysis of quantitative traits. Sinauer, Sunderland, MA.

Meuwissen, T. H. E. 1997. Maximising the response of selection with a predefined rate of inbreeding. Journal of Animal Science 75: 934-940.

Meuwissen, T. H. E. and Woolliams, J. A. 1994. Effective sizes of livestock populations to prevent a decline in fitness. Theoretical and Applied Genetics 89: 1019-1026.

O'Doherty, E., Healy, A., Aherne, M., Hanrahan, J. P., Weavers, E., Doherty, M., Roche, J. F., Gunn, M. and Sweeney, T. 2002. Prion protein (PrP) gene polymorphisms associated with natural scrapie cases and their flock-mates in Ireland. Research in Veterinary Science 73: 243-250.

Palhière, I., François, D., Elsen, J. M., Barillet, F., Amigues, Y., Perret, G. and Bouix, J. 2002. Allele frequencies of the PrP gene in 29 French sheep breeds. Possible use in selection for resistance to scrapie. Proceedings of the seventh world congress on genetics applied to livestock production, Montpellier, CD-ROM communication no. 13-13.

Sonesson, A. K., Janss, L. L. G. and Meuwissen, T. H. E. 2003. Selection against genetic defects in conservation schemes while controlling inbreeding. Genetics, Selection, Evolution 35: 353-368.

Vellema, P. 2002. Verplichte inzet ARR/ARR-rammen vanaf 1 juli 2004. Het Schaap 3: 16-17.

Wiener, G., Lee, G. J. and Woolliams, J. A. 1992. Effects of rapid inbreeding and crossing of inbred lines on conception rate, prolificacy and ewe survival in sheep. Animal Production 55: 115-121.

(Received 13 September 2003-Accepted 2 February 2004) 